\title{
D.H. Lawrence's Nostalgia and Longing for Life in Return to Bestwood
}

\author{
Xiuzhi Zhang \\ School of Foreign Studies, Xi'an University of Arts and Sciences, Xi'an 710065, China \\ 562205302@qq.com
}

Keywords: D.H. Lawrence; Return to Bestwood; Nostalgia; Longing for life.

\begin{abstract}
D.H. Lawrence's Return to Bestwood is a short prose with a strong nostalgia. The paper mainly analyzes Lawrence's nostalgia and his longing for life in Return to Bestwood. It expresses Lawrence 's eagerness for returning home and his yearning for his hometown, his long for a healthy life as well as his voices on his melancholy mood for his native land. The destruction of natural landscape and the changes of human nature in his hometown made him depressed and even urged him to brood on the value of life. The main purpose is to arouse people's awareness of life so that they can live an energetic life.
\end{abstract}

\section{Introduction}

We often say that nostalgia is a song, a cup of wine, a love knot, and special feeling of all life. Therefore, nostalgia becomes thousands of knots in many writers' hearts. "Nostalgia" means reminiscence: remember past times or old acquaintances with kindly thoughts. [1] So when one leaves his home and suffers many years' isolation, he has got a kind of feeling of missing people he was familiar with and his native land. Many writers and poets both at home and abroad try to express their homesickness in various forms. D.H.Lawrence is one of them. So Eastwood (Bestwood in Lawrence's works) became the source of his literature creation. In his works, he tried to pursue the original human nature, the simple lifestyle, and hoped that "The relationship between man and nature should be harmonious." [2]

Return to Bestwood is a culture lyric with the nostalgia and national tradition. It is intended to show the author's strong flavor of life, the pastoral scenery and the changes of human nature. Although Lawrence stayed on a strange land for many years, he never forgot Eastwood - the place that let him be lost in a reverie. In Return to Bestwood, he described the place Once a beautiful country place with hills around. The natural spring scenery was charming, with the green forests, fragrant flowers, and singing birds, while when the fall came, the water was clear with fish swimming freely, and everywhere people could see the charming, local scene. From the description, we know Lawrence cherished a deep concern for his birthplace. In his heart, "Hometown is much more beautiful than any other places in the world." [3] However, later, the extraction of coal in his hometown changed the old condition, and several coal mines appeared on the southern slope of the mountain, with the small town following. This change brought the destruction to the pastoral life, which destroyed the once idyllic scenery, and therefore it changed people's mood there. Finally Eastwood left the gray memory on Laurence's mind. However, even the fact was that, Laurence could not show his love not to his hometown.

\section{Yearning for his Hometown}

Nostalgia appears after one has roamed around years of life away from his hometown. If one never leaves home, he can not understand the meaning of the nostalgia. Only one has experienced leaving and returning his home can he have the feeling of missing and loving his home. Then he will never forget the place where he was born and bred, and his living experiences even arouse his memory. This kind of experience and memory is adrift in the nostalgic dream. After drifting for decades, Laurence wrote his Return to Bestwood to narrate his yearning for his native land.

Return to Bestwood tells the protagonist of "I"coming back home after a long absence of his birthplace, seeing the great changes of his homeland and the changes of people's mentality as well 
as their personal feelings. First the author described his returning to the Central Plains for a few days at the end of September after his wandering for nearly twenty years. He had a complex mood. "But in Nottingham Road, Bestwood, I feel at once a devouring nostalgia and an infinite repulsion." [4] Here, he was both missing his sweet home and also yearning for it. He was urgent to go home because those unforgettable breath and smell in the rural country were deeply buried in his soul and arouse his nostalgia. Finally, the remote feelings and spiritual nostalgia constituted a complete sense of time and space, and all these mood would naturally make Lawrence turn back to the previous original home. He remembered his childhood experiences when he passed by the cooperative, the small fence opposite it. Then he and his playmates often picked some flowers over the fence. He remembered Gabes Lane, and there was not much change in appearance. Here we can see his hometown was deeply rooted in his mind.

In the heart of Laurence, his hometown was a special charming place. In summer the green covered the mountains and the leafy shade even could prevent the noise of the traffic and the machines. Although having the ash and sulfur taste, the place was filled with natural pleasant fragrance. It seemed that one walked just like entering another country garden, coming to the forest and agriculture in England before. Lawrence once wrote in his letter: He had never known better than any places in the world. He understood every blade of grass and every tree and had the profound friendship to it. This was his hometown in his soul, and it was his hope and wish.

With his enthusiastic and honest attitude, Laurence spoke out his love for his homeland and showed his Nostalgia in his heart. Therefore, the grass, flowers and trees and the people in his homeland, very often appeared in his adult world and naturally touched his heart, leaving him in memory of his childhood. Here we see through the repression of the adult living environment, hometown as a strange memory reappears in the adult experience, resulting in people's nostalgia, imagination and desire for his hometown. So all in one's hometown and all the games in his childhood will bring the brilliant color and charm to his birthplace. So the "Hometown" as a cultural concept comes into the modern people's emotional life, entering into the literary theses, and Return to Bestwood undoubtedly reveals the psychological causes of this level.

\section{Worries and Grief at his Hometown}

Lawrence came back, only to find "her a strange place that had nothing to do with him." [4] He realized the changes in his homeland and then said his birthplace he had dreamed of made him feel strange and sad. Therefore, grief and desolation made Lawrence worry about his hometown and the people there..

The first is that the changes of natural appearance made him feel strange and sad. Just as what Laurence described: "It always depresses me to come to my native district." [4]Going home, he felt depressed. At this time Laurence was over forty and he wandered in foreign countries for almost twenty years. Now he came back, and the leaving and returning experiences just reminded him of the memory of vicissitudes of life. Now he felt very feel dejected, for "I feel more alien, perhaps, in my home place than anywhere else in the world." [4] He felt that his hometown was nothing like what he had in mind, so he felt more uncomfortable than in any other part of the world.

In Lawrence's heart, the beautiful Notts-Derby district became a coal area now. People could see coal mines everywhere, leaving a bad impression on them. The once old villages were buried in a row of houses. The paths of the fields were trampled and then became dirty and disorderly. So, wherever people went, they could see the sordid and filthy men. So Lawrence said: "...the uncanny sunniness which makes the Midlands peculiarly fearsome to me." [4] He had a sense of worries. Besides, the landscape of the garden near his sister's house was destroyed, and rows of houses were covered by coal dust, and the odour of sulphur permeated the air. Cars, trams and buses were running like a bat out of hell on the road. All these depressed Laurence, so he couldn't enjoy the pleasure that natural scenery brought to him. This was something that he could not accept. "Now, they rush and tear along the roads, and have joyrides and outings, but they never seem to touch the reality of the country-side." [4] Laurence felt overcrowded, yet isolated here. It seemed to him that his homeland was isolated and hard to reach. The devastation of the fields and the very crowded 
people made him sad. Standing in front of his homeland, the "spiritual returning" and "real returning" smashed his dream. [5]

The second is that the change of human nature made Lawrence disappointed. When he was young, it had been a disgrace for the coal miners to pick blackberries. But now scouring the countryside for blackberries was common. They picked and sold the blackberries to get four-pence. So "Their pride is in the pocket, and the pocket has a hole in it." [4] In Lawrence's heart, they had no pride and dignity, and this was the changes of humanity. In addition, it seemed that women also changed a lot. They showed no respect for all. A case lied in two women. A Mrs Hutton and a Mrs Rowley were taken to court to be tried because of their insulting and obstructing the police. In the past, they might feel shameful, but now they had no shame. Some decent women cheered, waving red flags, shouting for the two. Even those decent and educated people seemed to be proud of shouting in court. So the author felt very strange to his dreaming hometown and finally realized that people there lost themselves, and they were spiritless. Here, we can see human's virtue and morality were out of their mind. So this was really the tragedy of human nature, of the adverse factors of social development. He became unfamiliar to those folks who he had known before. They had betrayed the essence of beauty, and they had been changed spiritually.

Even more sadly, the relationship of the miners were quite indifferent. The miners were fishing, loafing, regardless of the notices around. They were numb and silent, with pale faces doing nothing. A group of policemen, alien, stood watching. Both sides pretended not be aware of each other. They had lost themselves in the society, showing no concern for the surroundings. They were all silent, and were completely in confrontation. Here we can see the variation of human nature: the gulf between man and man. It was not the scene that the author had remembered when he was young. At that time, their life was full of joy. When the workers were going home, their faces were ruddy, eyes were bright, and they came out of the mine greeting, shouting happily. That was something that left in Laurence's memory forever. But now, all these were gone. The vitality, the untamable ferity and impulse within themselves completely disappeared, even when they went to the football match, they were all inanimate. So Lawrence shouted: "Be a good animal, true to your animal instinct." [6] Lawrence wanted people to have the primitive power. He thought the blind development of the industry made people lost their spiritual life, their consciousness disappeared, and even their independent personality was gone. Therefore, Laurence "paid attention to man's inner world and tried to seek the road to natural, harmonious life." [7] Obviously, Laurence has held a positive attitude toward human nature, and he also has held the wise foresight to eliminate the social evils.

\section{Longing for a Healthy Life}

Laurence loved his native land. He liked everything there: the small mountain town, animals, flowers, grass and forests and he regarded the whole creation in his hometown as the key of life. This place was his spiritual support. [8]However, with joy and pleasure, he reunited his hometown, and he felt he had some connection with people's fate here. He believed that even in other places, what he missed most was the people in his hometown. He could help arising his nostalgia spontaneously. But in fact, when he came back, what he had seen was the miserable life. He felt pain and depressed. He was deeply disturbed by the changes of human nature and felt his homeland had been shrouded in a shadow of chaos and failure, and people's minds were full of confusion and disappointment. So, every place he went, he felt that an inexplicable sadness and disappointment locked his heart.

The failure and the melancholy took him into the consideration of the meaning of life. Then, he hoped to return to human nature and emphasized the positive views toward life, that was the call for real life. He spent all his life in search of his own soul, and wished to live a life full of natural vitality; therefore, his point is "to be a whole man alive." [9] and to have a better, healthy life. He said though he was always poor in health, but he had strong life. This is a gladiator's life motto. Laurence's call for human life is his concern for human and all the world. Laurence thought that unplanned development was the obstacle for the human revitalization, and modernization was the root of the backward-looking human. He hoped England would become a new democratic country 
little by little, and everything would be going smooth. From the analysis, we see Laurence stressed that "people should pursue higher individual life and tried to raise their life to the highest level." [10] This fully shows a writer's hope for his country, his expectation for the future and his respect for life.

\section{Conclusion}

Lawrence has pursued the instinct of life, natural life. For Lawrence, the understanding of life was alive. So man should stress the quality of life in preference to the quantity of life. He believed that the birth rate should be controlled, besides, people need to recognize that the world is changing greatly and the development should be done in the planned way, otherwise the blind development will bring suffering. So, in some extent, Laurence has foreseen the development of industrial civilization. He has been in the pursuit of the meaning of life, the vitality of beauty. what Laurence concerned and called for is the healthy life. Thus, Lawrence's views of life are very conductive to the value of people's life and also very beneficial to their health.

\section{Reference}

[1] Information on http://baike.baidu.com

[2] Q.Z. Ma: D.H.Lawrence's Humanist and Ecological View, Xi'an University of Arts and Sciences.Vol.15(2012) No.3, p.40-42 (in Chinese)

[3] F.G. Miao: D.H.Lawrence from the Perspective of Eco-criticism ( Shanghai University Press, Shanghai2007), p.038-040 (in Chinese)

[4] B.T. Zhang: D.H.Lawrence: Selected Literary Critiques (Shanghai Foreign Language Education Press, Shanghai 2003), p.28-40

[5] X.Z. Zhang: A Longing for Hometown in the Soul and the Call of Life in Sadness after Returning to his Hometown-An Interpretation and Reflection of D.H.Lawrence's Nostalgia in Return to Bestood, Journal of Shenyang Institute of Engineering, Vol.10(2014)No.3,p.378 (in Chinese)

[6] A. Fernihough: D.H.Lawrence (Shanghai Foreign Language Education Press, Shanghai 2004), p.16.

[7] J.H. Yu: English \& American Literary Studies, third ed., (Shanghai Foreign Language Education Press, Shanghai2002) p.54. (in Chinese)

[8] Y. Cheng, J. Zou: Life Worshiped as God: An Analysis on D.H.Lawrence's life Worship Philosophy, Journal of Shengyang University, Vol.18(2016)N0.3,P.321 (in Chinese)

[9] Z.M. Wang: D.H.Lawrence's Concept of Life-An Ecocritical Study of D.H.Lawrence's The Rainbow and Women in Love (MS., Shanghai International Studies University, Shanghai2008) p.26 (in Chinese)

[10]H.T. Liu: Wasteland and Rescue: Lawrence's Novels in Modernism Context (China Social Sciences Press, Beijing 2007),p.246(in Chinese). 